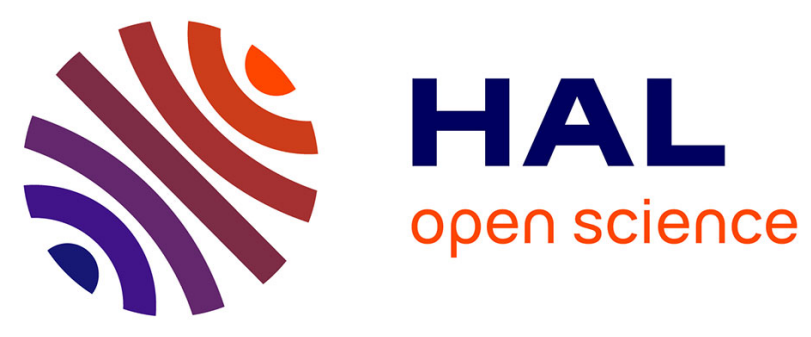

\title{
Serum microRNAs and antifibrotic response to eplerenone in acute myocardial infarction complicated by systolic dysfunction
}

Susan Stienen, João Pedro Ferreira, Christian Bär, Thomas Thum, António Barros, Bertram Pitt, Nicolas Girerd, Patrick Rossignol, Faiez Zannad

\section{To cite this version:}

Susan Stienen, João Pedro Ferreira, Christian Bär, Thomas Thum, António Barros, et al.. Serum microRNAs and antifibrotic response to eplerenone in acute myocardial infarction complicated by systolic dysfunction. International Journal of Cardiology, 2021, S0167-5273 (21), pp.00399-5. 10.1016/j.ijcard.2021.02.088 . hal-03166560

\section{HAL Id: hal-03166560 \\ https://hal.univ-lorraine.fr/hal-03166560}

Submitted on 19 Mar 2021

HAL is a multi-disciplinary open access archive for the deposit and dissemination of scientific research documents, whether they are published or not. The documents may come from teaching and research institutions in France or abroad, or from public or private research centers.
L'archive ouverte pluridisciplinaire HAL, est destinée au dépôt et à la diffusion de documents scientifiques de niveau recherche, publiés ou non, émanant des établissements d'enseignement et de recherche français ou étrangers, des laboratoires publics ou privés. 


\section{Serum microRNAs and antifibrotic response to eplerenone in acute myocardial}

2 infarction complicated by systolic dysfunction

3 Susan Stienen, MD, $\mathrm{PhD}^{1,2}$; João Pedro Ferreira, $\mathrm{MD}, \mathrm{PhD}^{1,3}$; Christian Bär, $\mathrm{PhD}^{4}$; Thomas

4 Thum $\mathrm{MD}, \mathrm{PhD}^{4}$; António Barros, $\mathrm{PhD}^{3}$; Bertram Pitt, $\mathrm{MD}, \mathrm{PhD}^{5}$; Nicolas Girerd, $\mathrm{MD}$,

$5 \quad \mathrm{PhD}^{1}$, Patrick Rossignol, $\mathrm{MD}, \mathrm{PhD}^{1}$; Faiez Zannad, $\mathrm{MD}, \mathrm{PhD}^{1}$

$6{ }^{1}$ Université de Lorraine, INSERM, Centre d'Investigations Cliniques Plurithématique 1433,

7 INSERM U1116, CHRU de Nancy, F-CRIN INI-CRCT, Nancy, France; ${ }^{2}$ Department of

8 Cardiology, Amsterdam University Medical Centers, Amsterdam, the Netherlands; ${ }^{3}$

9 Cardiovascular Research and Development Unit (UnIC), Department of Surgery and

10 Physiology, Faculty of Medicine, University of Porto, Porto, Portugal; ${ }^{4}$ Institute of Molecular

11 and Translational Therapeutic Strategies (IMTTS), Hannover Medical School, Hannover,

12 Germany; ${ }^{5}$ Department of Medicine, University of Michigan School of Medicine, Ann

13 Arbor;US

14

15 Address for correspondence:

16 Prof. Faiez Zannad

17 Centre d'Investigation Clinique 1433 module Plurithématique

18 CHRU Nancy - Hopitaux de Brabois

19 Institut Lorrain du Coeur et des Vaisseaux Louis Mathieu

204 rue du Morvan, 54500 Vandoeuvre les Nancy

$21 \quad$ Tel : +33(0) 383157315

$22 \quad$ Fax: $+33(0) 383157324$

23 Mail:f.zannad@chru-nancy.fr

Disclosures

26 The EPHESUS trial was sponsored by Pfizer. BP, JM and FZ were members of the steering 27 committees. BP is a consultant for Bayer, Astra Zeneca, Sanofi, KBP Biosciences*, Sarfez*, 28 Relypsa/ Vifor*, Tricida*, Stealth Peptides.*=stock options. He holds a patent for site-

29 specific delivery of eplerenone to the myocardium (US patent \# 9931412). All other authors 30 have no conflicts of interest to declare. 


\section{Funding:}

2 SS, JF, FZ and PR are supported by a public grant overseen by the French National Research

3 Agency (ANR) as part of the second "Investissements d'Avenir" program FIGHT-HF

4 (reference: ANR-15-RHU-0004) and by the French PIA project "Lorraine Université

5 d'Excellence", reference ANR-15-IDEX-04-LUE, and by the Contrat de plan Etat-lorraine

6 and FEDER lorraine. SS received funding from the European Society of Cardiology in form

7 of an ESC Research Grant (R-2018-18686). TT was supported by the German Research

8 Foundation (DFG Th903/18-1) and the ERANet Grant EXPERT (BMBF, Germany, research

9 grant ERA-CVD JTC2016 EXPERT, 01KL1711). AB was supported by DOCnet (NORTE-

10 01-0145-FEDER-000003), by Norte Portugal Regional Operational Programme (NORTE

11 2020), under the PORTUGAL 2020 Partnership Agreement, through the European Regional

12 Development Fund (ERDF).

13

14

15

16 


\section{Abstract}

\section{Background}

3 After myocardial infarction (MI) complicated by heart failure (HF), eplerenone reduced

4 serum concentrations of amino-terminal propeptide of type III collagen (PIIINP) and carboxy5 terminal propeptide of type I collagen (PICP). Determining a subgroup who are more prone to 6 decrease their collagen content and to respond better to the antifibrotic effects of 7 mineralocorticoid receptor antagonists (MRA) may be relevant for a personalized treatment 8 approach. Whether circulating microRNAs may identify a subgroup that have experienced a 9 more pronounced antifibrotic effect of eplerenone as measured by a PICP and PIIINP 10 decrease is unclear.

11 Methods

12 A set of circulating microRNAs linked to cardiac fibrosis (mir-1, mir-21, mir-29a, mir-29b, 13 mir-101, mir-122, mir-133a) were measured at baseline in 198 patients in the biomarker 14 substudy of Eplerenone Post-Acute Myocardial Infarction Heart Failure Efficacy and Survival 15 Study (EPHESUS). Associations between baseline microRNA levels and changes in both 16 PIIINP and PICP from baseline to month 9 were studied using multivariable analysis of covariance, adjusting for age, sex, history of hypertension and diabetes mellitus, prescription of ACE-inhibitors or angiotensin receptor blockers, baseline PIIINP or PICP, and eplerenone treatment. Furthermore, a treatment-by-microRNA interaction was studied.

\section{Results}

21 From the selected microRNAs, only mir-133a was associated with a PICP decrease (ß-6.43, $2295 \%$ CI-12.71 to $-0.15, \mathrm{p}=0.045)$. None of the microRNAs was associated with a PIIINP change. The microRNAs did not predict an effect of eplerenone on PICP and PIIINP changes. Conclusion

Although serum mir-133a was associated with PICP change, none of the microRNAs previously linked to cardiac fibrosis predicted an antifibrotic response to eplerenone. Further study is needed to identify other suitable targets for a personalized treatment approach. 


\section{Background}

2 Eplerenone reduced morbidity and mortality in patients with an acute myocardial infarction

3 (MI), complicated by systolic dysfunction, HF or diabetes mellitus in the Eplerenone Post-

4 Acute Myocardial Infarction Heart Failure Efficacy and Survival Study (EPHESUS) ${ }^{1}$. In post-

5 hoc analyses of the trial, eplerenone reduced the serum concentrations of amino-terminal

6 propeptide of type III collagen (PIIINP) and carboxy-terminal propeptide of type I collagen

7 (PICP $)^{2,3}$. These biomarkers have been linked to collagen synthesis and associated with

8 histopathological myocardial fibrosis ${ }^{4}$. Hence, it has been postulated that the beneficial

9 treatment effect of eplerenone (and other mineralocorticoid receptor antagonists - MRAs)

10 could be, at least partially, mediated by its antifibrotic effect. Identifying the subset of patients

11 who may respond better to the antifibrotic effects of MRA therapy is pertinent for a

12 personalized treatment approach. We have previously shown in an EPHESUS substudy that

13 patients with higher baseline PIIINP levels experienced a better treatment response to

14 eplerenone $e^{5}$. Circulating microRNAs (short RNA sequences that regulate gene expression)

15 have also been linked to collagen turnover ${ }^{4,6}$. We thus hypothesised that a few selected

16 microRNAs could identify a subgroup of patients who might have experienced a more

17 pronounced antifibrotic effect of eplerenone as measured by a PICP and PIIINP decrease.

Methods

In this biomarker substudy of EPHESUS, a set of circulating microRNAs previously linked to

21 cardiac fibrosis (mir-1, mir-21, mir-29a, mir-29b, mir-101, mir-122, mir-133a (as reviewed by

22 Thum $^{6}$ ) were measured at baseline in 198 patients. A detailed account of the methods of this

23 biomarker substudy has been previously published ${ }^{2}$. The number of patients included in this

24 specific substudy was lower than the original biomarker substudy $(n=476)$ since not all

25 patients had enough sample volume left for the microRNA measurements. 
Total RNA was isolated from $150 \mu$ l plasma samples using miRNeasy Serum/Plasma

2 Advanced Kit (Qiagen, Hilden, Germany). Reverse transcription reactions were performed using the Reverse Transcription TaqMan MicroRNA Reverse Transcription Kit (Applied

4 Biosystems ${ }^{\circledR}$, Darmstadt, Germany). For each reaction, $2.5 \mu 1$ of RNA was used. All procedures were performed according to the manufacturers' instructions. After qPCR, starting quantities (N0) of each microRNA were normalized to N0 to the geometric mean of cel-miR39-3p and miR- 486- $5 \mathrm{p}$ (Relative quantity $=\mathrm{NO}_{\text {miR }} / \sqrt{ }\left(\mathrm{N} 0_{\text {cel-miR-39-3p }} * \mathrm{~N} 0_{\text {miR- }}-486-5 \mathrm{p}\right)$ ). Associations between baseline microRNA levels and changes in both PIIINP and

9 PICP from baseline to month 9 were studied using multivariable analysis of covariance, 10 adjusting for age, sex, baseline PIIINP or PICP, history of hypertension or diabetes mellitus, 11 prescription of ACE inhibitors or angiontensin receptor blockers and eplerenone treatment. Furthermore, a treatment-by-microRNA interaction was studied.

\section{Results and discussion}

A total of 96 patients (49\%) were randomized to eplerenone treatment. Baseline levels of microRNAs did not differ between patients treated with eplerenone versus placebo (all pvalues >0.1). MicroRNAs were not significantly correlated with baseline PICP and PIIINP (including when the correlations were assessed in the eplerenone and placebo groups, separately), although some microRNAs showed a moderate correlation between them (data not shown). Only mir-133a was associated with a change in PICP (B-6.43, 95\% CI-12.71 to $0.15, \mathrm{p}=0.045$, Table $)$ None of the microRNAs measured at baseline was associated with a change in PIIINP. The microRNAs did not predict an effect of eplerenone on PICP and PIIINP changes (Table).

24 There were no significant associations between the microRNAs and clinical outcomes (allcause mortality and cardiovascular (CV) death / CV readmissions) (data not shown). 
Mir-133a, one of the most abundant miRNAs in the heart, plays a role in the early

2 phase after MI and subsequent cardiac remodeling and is increased in MI patients ${ }^{7}$. In this study, higher circulating mir-133a levels were independently associated with a decrease in

4 PICP, which may suggest an antifibrotic response. In line with our findings, increased baseline mir-133a levels were associated with reverse cardiac remodeling in dilated cardiomyopathy ${ }^{8}$. Interestingly, mir-133a was also previously found to be a direct target of the collagen 1 (Col1A1) gene where its downregulation was associated with Col1A1 overexpression and hence myocardial fibrosis ${ }^{9}$. Despite not being able to identify a subset of patients more likely to respond to eplerenone (probably due to the small sample size and lack of power to study interactions), further research is needed to study the utility of mir-133a as a

11 fibrosis marker.

Some additional limitations should be acknowledged. First, the substudy population differed from the main EPHESUS cohort with respect to baseline characteristics, the timing of treatment initiation, and outcomes ${ }^{2}$. Extrapolation of the results of this study to the whole EPHESUS population should, therefore, be made with caution. Second, a detailed characterization of cardiac function and fibrosis (e.g., with cardiac MRI) was not available in our data; in consequence, cardiac fibrosis was indirectly assessed by the evaluation of collagen synthesis biomarkers, that have been shown to correlate directly with cardiac fibrosis in previous research ${ }^{4}$. Third, the microRNAs selected for this study had been previously associated with cardiac fibrosis; in consequence, we cannot exclude that other unmeasured 21 microRNAs could predict an antifibrotic response. Lastly, event rates were very low in this 22 present study, precluding any conclusions regarding the associations between microRNAs, eplerenone treatment and clinical outcomes such as hospitalizations or death. In conclusion, although serum mir-133a was independently associated with PICP change, none of the circulating microRNAs previously linked to cardiac fibrosis predicted an 
1 antifibrotic response to eplerenone treatment in patients after an acute MI complicated by left

2 ventricular dysfunction and/or heart failure. Further study is needed to identify other suitable 3 targets for a personalized treatment approach.

4

5

6

7

8

9

10

11

12 
Table 1. Multivariable linear regression analyses on associations between microRNAs and PICP and PIIINP changes with a treatment-by-miR interaction

\begin{tabular}{|c|c|c|c|c|c|c|c|c|}
\hline & \multicolumn{4}{|c|}{$\Delta$ PICP (M0-M9) } & \multicolumn{4}{|c|}{ DPIIINP (M0-M9) } \\
\hline & $\beta$ & $95 \% \mathrm{CI}$ & $\mathrm{p}$-value & $\begin{array}{l}\text { Interaction }^{\mathrm{p}} \text { for } \\
\text { treatment*miR }\end{array}$ & $\beta$ & $95 \% \mathrm{CI}$ & p-value & $\begin{array}{l}\text { Interaction }^{\mathrm{p}} \\
\text { for } \\
\text { treatment*miR }\end{array}$ \\
\hline \multicolumn{9}{|l|}{ Model } \\
\hline Age & -0.29 & -0.82 to 0.24 & 0.28 & & 0.01 & -0.01 to 0.02 & 0.53 & \\
\hline Male sex & 13.94 & 0.47 to 27.41 & 0.04 & & -0.44 & -0.78 to -0.10 & 0.01 & \\
\hline Hypertension & 13.67 & 1.68 to 25.67 & 0.03 & & 0.48 & 0.18 to 0.78 & 0.002 & \\
\hline Diabetes mellitus & -17.89 & -30.38 to -5.40 & 0.005 & & -0.13 & -0.46 to 0.20 & 0.44 & \\
\hline ACEi or ARB use & -1.40 & -17.55 to 14.75 & 0.86 & & 0.05 & -0.34 to 0.44 & 0.78 & \\
\hline Eplerenone treatment & -13.43 & -24.53 to -2.33 & 0.02 & & -0.49 & -0.78 to -0.20 & 0.001 & \\
\hline Baseline PIIINP & & & & & -0.59 & -0.69 to -0.49 & $<0.001$ & \\
\hline Baseline PICP & -0.77 & -0.88 to -0.65 & $<0.001$ & & & & & \\
\hline \multicolumn{9}{|l|}{$\begin{array}{l}\text { Model + individual } \\
\text { MiRNAs }\end{array}$} \\
\hline MiR-1 & 0.03 & -4.70 to 4.75 & 0.99 & 0.97 & -0.01 & -0.15 to 0.15 & 0.98 & 0.31 \\
\hline MiR-21 & 0.70 & -8.77 to 10.16 & 0.89 & 0.78 & -0.20 & -0.48 to 0.08 & 0.17 & 0.98 \\
\hline MiR-29a & -2.15 & -12.58 to 8.29 & 0.69 & 0.17 & -0.04 & -0.36 to 0.28 & 0.82 & 0.73 \\
\hline MiR-29b & -2.50 & -10.85 to 5.84 & 0.55 & 0.59 & 0.03 & -0.25 to 0.31 & 0.83 & 0.89 \\
\hline MiR-101 & -4.72 & -18.17 to 8.74 & 0.49 & 0.26 & -0.19 & -0.59 to 0.22 & 0.36 & 0.12 \\
\hline MiR-122 & -0.31 & -4.75 to 4.13 & 0.89 & 0.24 & -0.01 & -0.13 to 0.14 & 0.89 & 0.45 \\
\hline MiR-133a & -6.43 & -12.71 to -0.15 & 0.045 & 0.08 & -0.10 & -0.30 to 0.10 & 0.33 & 0.54 \\
\hline
\end{tabular}

Legend: PICP, carboxy-terminal propeptide of procollagen type I; PIIINP, amino-terminal propeptide of type III procollagen; $\triangle \mathrm{PIIINP}$ (M0-M9), absolute change in PIIINP from baseline to month 9; $\triangle \mathrm{PIIINP}$ (M0M9), absolute change in PIIINP from baseline to month 1; MiR, microRNA; ACEi, angiotensin-converting enzyme inhibitor; ARB, angiotensin receptor blocker 


\section{References}

1. Pitt B, Remme W, Zannad F, et al. Eplerenone, a selective aldosterone blocker, in patients with left ventricular dysfunction after myocardial infarction. $N$ Engl J Med. Apr 3 2003;348(14):1309-21. doi:10.1056/NEJMoa030207

2. Iraqi W, Rossignol $\mathrm{P}$, Angioi $\mathrm{M}$, et al. Extracellular cardiac matrix biomarkers in patients with acute myocardial infarction complicated by left ventricular dysfunction and heart failure: insights from the Eplerenone Post-Acute Myocardial Infarction Heart Failure Efficacy and Survival Study (EPHESUS) study. Circulation. May 12 2009;119(18):2471-9. doi:10.1161/circulationaha.108.809194

3. Stienen S, Ferreira JP, Pitt B, et al. Eplerenone prevents an increase in serum carboxyterminal propeptide of procollagen type I after myocardial infarction complicated by left ventricular dysfunction and/or heart failure. Eur $J$ Heart Fail. Apr 2020;doi:10.1002/ejhf.1812

4. Lopez B, Gonzalez A, Ravassa S, et al. Circulating Biomarkers of Myocardial Fibrosis: The Need for a Reappraisal. J Am Coll Cardiol. Jun 9 2015;65(22):2449-56. doi:10.1016/j.jacc.2015.04.026

5. Stienen S, Rossignol P, Barros A, et al. Determinants of anti-fibrotic response to mineralocorticoid receptor antagonist therapy: insights from the Eplerenone Post-Acute Myocardial Infarction Heart Failure Efficacy and Survival Study (EPHESUS) and Early Eplerenone Treatment in Patients with Acute ST-elevation Myocardial Infarction without Heart Failure (REMINDER) trials. Clin Res Cardiol. Feb 2020;109(2):194-204. doi:10.1007/s00392-019-01500-3

6. Thum T. Noncoding RNAs and myocardial fibrosis. Nat Rev Cardiol. Nov 2014;11(11):655-63. doi:10.1038/nrcardio.2014.125

7. Widera C, Gupta SK, Lorenzen JM, et al. Diagnostic and prognostic impact of six circulating microRNAs in acute coronary syndrome. $J$ Mol Cell Cardiol. Nov 2011;51(5):872-5. doi:10.1016/j.yjmcc.2011.07.011

8. Dziewięcka E, Totoń-Żurańska J, Wołkow P, et al. Relations between circulating and myocardial fibrosis-linked microRNAs with left ventricular reverse remodeling in dilated cardiomyopathy. Adv Clin Exp Med. Mar 2020;29(3):285-293. doi:10.17219/acem/115088

9. Castoldi G, Di Gioia CR, Bombardi C, et al. MiR-133a regulates collagen 1A1: potential role of miR-133a in myocardial fibrosis in angiotensin II-dependent hypertension. $J$ Cell Physiol. Feb 2012;227(2):850-6. doi:10.1002/jcp.22939 